\title{
Meat quality characteristics of exotic and SPRD crossbred goats from the semiarid region
}

\author{
Qualidade da carne de caprinos exóticos e mestiços SPRD da região semiárida
}

Ertha Janine Lacerda de MEDEIROS ${ }^{1 \star}$, Francisco Harley de Oliveira MENDONÇA ${ }^{1}$, Rita de Cássia Ramos do Egypto QUEIROGA², Marta Suely MADRUGA ${ }^{1}$

\begin{abstract}
Thirty-two intact male goats from four genetic groups (eight pure-bred Boers, eight $3 / 4$ Boer $+1 / 4$ SPRD crossbreeds, eight $1 / 2$ Boer $+1 / 2$ SPRD crossbreeds, and eight $1 / 2$ Anglo Nubian $+1 / 2$ SPRD crossbreeds) were evaluated for meat quality. The goats were reared in confinement and slaughtered at the average live weight of $29 \mathrm{~kg}$. Temperature and $\mathrm{pH}$ decrease in the longissimus dorsi muscle was determined for 24 hours, and analyses of colour, cooking loss, water-holding capacity, and sensory attributes were also performed. Genotype significantly (P < 0.05$)$ influenced the confinement period; $1 / 2$ Boer $+1 / 2$ SPRD crossbreeds required the most time in confinement to reach the target weight, while the pure-bred Boers required the least time. Genotype also significantly influenced $(\mathrm{P}<0.05)$ the weight loss due to cooking, shearing force, colour (intensity of yellowness and luminescence), and the sensory attributes of flavour, odour, and raw colour of the meat. The crossing of exotic Boer and Anglo Nubian breeds with the native SPRD resulted in a goat meat of high quality.

Keywords: anglo nubian; boer; genotypes; goat; meat quality; SPRD.
\end{abstract}

\section{Resumo}

Trinta e dois caprinos machos não castrados de quatro grupos genéticos, oito da raça Boer Puro, oito mestiços de 3/4 Boer + 1/4 SPRD, oito mestiços de $1 / 2$ Boer $+1 / 2$ SPRD e oito mestiços de $1 / 2$ Anglo Nubiano $+1 / 2$ SPRD, foram utilizados para caracterizar a sua qualidade de carne. Os caprinos foram criados em confinamento e abatidos com o peso vivo médio de $29 \mathrm{~kg}$. Em conjunto com as análises de cor, foram determinados o decréscimo da temperatura e do $\mathrm{pH}$ durante 24 horas no músculo longissimus dorsi, a perda de peso por cocção, a capacidade de retenção de água e sensoriais. O genótipo $(\mathrm{p}<0,05)$ influenciou significativamente o período de confinamento: mestiços de $1 \frac{1}{2}$ Boer $+1 / 2$ SPRD apresentaram maior número de dias em confinamento, enquanto os Boer Puro alcançaram o peso final no menor período de dias. O genótipo também influenciou significativamente $(\mathrm{p}<0,05)$ os parâmetros de perda de peso por cocção, força de cisalhamento e cor (intensidade de amarelo e luminescência) e os atributos sensoriais de sabor, odor e cor de carne crua. O cruzamento das raças Boer e Anglo Nubiana com os nativos SPRD resultou em carne caprina de elevada qualidade.

Palavras-chave: anglo nubiano; boer; carne caprina; genótipos; qualidade da carne; SPRD.

\section{Introduction}

The Northeast region of Brazil, one of the driest in the world, has over $90 \%$ (9.3 million) of the goat population of the country (INSTITUTO..., 2008). These goats are an extremely important economic alternative for people who live in this area; the animals are well adapted to the harsh environment and limited feed, and goat herders are able to use marginal land to produce meat (MADRUGA et al., 2005).

The Northeast flock is composed mainly of local wild-type goats, named SPRD goats, which are well adapted to the dryness of the semiarid region of Brazil. Increased meat production is necessary to improve the economic income of the Northeast region, especially higher carcass yield, better quality, and conformation. Goat rearers generally prioritise the production of high-quality meat (WEBB; CASEY; SIMELA, 2005). This can be achieved with genetic improvement, namely by crossing the characteristic adaptability of native breeds with the best quality meat of exotic breeds. Genotype plays an important factor in goat rearing systems because it influences the rate of growth and weight gain as well as the feed conversion ratio; all of which are related to meat quality. According to Madruga et al. (2008), the evaluation of a breed for meat production begins with the study of its ability to gain weight, which is associated with the chemical and sensory quality of the meat. Madruga (2004) and Pratiwi, Murray and Taylor (2007) reported that goat meat has nutritional advantages over other red meats available on the market, such as a low level of fat and high levels protein, iron, and unsaturated fatty acids.

Among the breeds of goats, Anglo Nubians and Boers have been reported as the best for use in crosses to increase meat production. The Boer breed, when fed a good diet, has a high

\footnotetext{
Received 18/10/2010

Accepted 26/7/2012 (005102)

${ }^{1}$ Graduate Program in Science and Food Technology - PPGCTA, Technology Center - CT, Federal University of Paraiba - UFPB,

Campus I, CEP 58059-900, João Pessoa, PB, Brazil, e-mail: erthajanine@yahoo.com.br

${ }^{2}$ Department of Nutrition - DN, Federal University of Paraiba - UFPB, Campus I, CEP 58059-900, João Pessoa, PB, Brazil

${ }^{*}$ Corresponding author
}

DOI: http://dx.doi.org/10.1590/S0101-20612012005000102 
rate of prolificacy and yields large amounts of high-quality meat (SHRESTH; FAHMY, 2005). In addition, some producers have used the Anglo Nubian breed in crosses because it has both good meat and good milk (MADRUGA et al., 2009).

The most important quality characteristic of red meat, which determines the overall acceptability of the cut, is appearance (colour and brightness), which is responsible for consumer acceptance at the time of purchase and perceived softness. Various quality parameters, such as $\mathrm{pH}$, water retention, and colour are interdependent and must be analysed together. The degree of quality varies according to the views and interests of farmers, food industries, grocers, and especially the consumer (MONTE et al., 2007).

There are few published reports comparing the meat quality of crossbreeds of Boer, Anglo Nubian and Brazilian SPRD goats. Because information on the meat quality of Boer and Anglo Nubian goats has been directed at their countries of origin, and because the meat quality of crossbred Boer, Anglo Nubian and SPRD goats in the semiarid area of Brazil has not yet been established, the present study was conducted to investigate the quality of meat obtained from these crossbreeds.

\section{Materials and methods}

\subsection{Animals and diet}

The present study was conducted using 32 intact male goats from four crossbreeds of Boer, Anglo Nubian and SPRD: 8 purebred Boers; 8 3/4 Boer + 1/4 SPRD goats; $8 \frac{1}{1 / 2}$ Boer $+1 / 2$ SPRD goats; and $8 \frac{1}{2}$ Anglo Nubian $+1 / 2$ SPRD goats. The animals were selected, based on weight, from the flock of the Pendency Experimental Station, which belongs to the State of Paraiba Agricultural and Cattle Raising Research Company - EMEPAPB. The selected goats had an average weight of $18.0 \pm 1.0 \mathrm{~kg}$, and they were, on average, $135.0 \pm 2.0$ days of age. During the confinement period, the animals were identified, weighed, submitted to health control, and housed in individual cages measuring $0.80 \mathrm{~m}$ wide by $1.20 \mathrm{~m}$ in length with feeders and waterers were arranged along a hallway.

The animals were allowed 14 days to adapt to the stalls and diet. From this point on, the animals were kept in confinement under the same experimental diet (Table 1), balanced in accordance with the requirements of the NRC (NATIONAL..., 1981), until they reached the slaughter weight of $29.0 \pm 2.0 \mathrm{~kg}$.

At the end of the confinement period, the animals were submitted to solid fasting and free water for 16 hours; they were slaughtered in accordance with the RIISPOA standards (BRAZIL, 2008). The carcasses were identified according to animal and genotype and stored in a cold room, where they were kept for 24 hours at $2{ }^{\circ} \mathrm{C} \pm 0.5^{\circ} \mathrm{C}$. The $\mathrm{pH}$ and temperature of the longissimus dorsi, on the right side, were assessed at 0 hours, 1 hours, 5 hours, 10 hours, 15 hours, 20 hours, and 24 hours after slaughter with a digital potentiometer, model 205 (TESTO, São Paulo, Brazil), which was calibrated with buffer solutions at pH 7.0 and pH 4.0 (ASSOCIATION..., 2000).
Samples of the longissimus dorsi muscle were vacuum packed and stored at $-20^{\circ} \mathrm{C}$ for a period not longer than 60 days before physical and sensorial analyses. The meat was thawed on the night before the analysis, and all physical analyses were performed in triplicate.

\subsection{Evaluation of meat quality}

The surface colour of the longissimus dorsi muscle was measured after a $30 \mathrm{~min}$-bloom at room temperature (Minolta Chroma-Meter, CR 300, Minolta, Japan). Colour measurements were taken in the CIE $L^{*}, a^{*}, b^{*}$ system (where $L^{*}$ measures relative lightness, $\mathrm{a}^{\star}$ relative redness, and $\mathrm{b}^{\star}$ relative yellowness) following the method described by Abularach, Rocha e Felicio (1998). The mean of three measurements was taken across the same cross section of muscle avoiding areas of connective tissue or intramuscular fat. The Colorimeter was calibrated with a red tile $(Y=15.6 ; \mathrm{x}=0.446 ; \mathrm{y}=0.313)$ before measuring colour. The measuring head was set to D65 illuminant with the $2^{\circ}$ standard observer and an $8 \mathrm{~mm}$ aperture.

Weight loss due to cooking (LWC) was calculated by weighing cubes of muscle wrapped in aluminium foil and subsequently cooking them in an oven pre-heated to $170{ }^{\circ} \mathrm{C}$ until the internal temperature of the meat reached $71{ }^{\circ} \mathrm{C}$ (DUCKETT et al., 1998a). For verification, a copper/constatan thermocouple model HD9218 (Delta OHM, Caselle di Selvazzano, Italy) equipped with a digital display was used. The samples were then allowed to cool at room temperature, patted dry with paper towels, and reweighed. Losses during cooking were calculated by the difference in weight before and after cooking and are expressed as a percentage $\left(\mathrm{g} .100 \mathrm{~g}^{-1}\right)$. These samples were also used in textural analyses.

Table 1. Ingredients and chemical composition of the diet fed to four breeds of goat.

\begin{tabular}{lc}
\hline \multicolumn{1}{c}{ Ingredients } & \% Dry matter \\
\hline Tifton hay (Cynodon dactylon, (L.) Pers) & 33.0 \\
Ground corn & 39.0 \\
Soybean meal & 11.5 \\
Cotton meal & 7.0 \\
Wheat meal & 7.0 \\
Mineral salt & 1.0 \\
Limestone & 1.5 \\
& Chemical composition \\
Dry matter & 90.0 \\
Crude protein & 17.1 \\
Mineral matter & 6.9 \\
Organic matter & 93.1 \\
Ether extract & 3.6 \\
Neutral detergent fibre & 30.0 \\
Total carbohydrate & 72.4 \\
Acid detergent fibre & 14.0 \\
Calcium & 2.04 \\
Phosphorus & 0.99 \\
Metabolisable energy (Mcal of ME/kg of DM) & 2.8 \\
\hline
\end{tabular}


The texture was evaluated by measuring the shear force (SF) according to methodology described by Duckett et al. (1998b). Strips $(1.3 \mathrm{~cm} \times 1.3 \mathrm{~cm})$ parallel to the muscle fibre axis were taken from each sample and sheared perpendicular to this axis using a Warner-Bratzler shearing (WBS) device equipped with a Stable Micro System TA-XT2 (Surrey, England). The crosshead speed was maintained at $20 \mathrm{~cm} /$ minutes.

To measure the water-holding capacity (WHC), a sample (approximately $1 \mathrm{~g}$ ) of the ground raw meat was transferred into a centrifuge tube containing $20 \mathrm{~mL}$ of cold distilled water and submitted to centrifugation in a model 206BL centrifuge (EXCELSA, São Paulo, Brazil) at $10.000 \mathrm{rpm}$ for 10 minutes. The supernatant was removed and its volume was subtracted from the $20 \mathrm{~mL}$ total volume. The result is expressed as a percentage of water expelled (MILLER; GRONINGER JUNIOR, 1978).

For the sensory evaluation of the goat meat, the most important attributes to describe the quality of the cooked meat were selected: odour, colour, hardness, juiciness, flavour, and overall palatability. The sensory tests were performed by a team of nine trained judges composed of five men and four women (four were between 20 and 30 years of age, and three between 31 and 40 and two over 41). The team was previously selected and trained according to the methodology described by Stone et al. (1974). The intensity of each attribute was evaluated on a ninecentimetre non-structured scale, which was anchored at the extremities with terms that express intensity (very and little) in three repetitions. The project was approved by the Ethics Committee of the University Federal of Paraiba (project number 157/2009), which is recognised by National Research Ethics.

Portions of $200 \mathrm{~g}$ were cut into cubes of $1 \mathrm{~cm}^{3}$, which were cooked using the same method described above for shear force measurements. Four randomly selected cubes of cooked meat were transferred directly into a pre-warmed, clean, $100 \mathrm{~mL}$-glass beaker labelled with three-digit random numbers. The beakers were covered to ensure that the escape of volatiles and aroma was minimal and placed in an oven at $65^{\circ} \mathrm{C}$ to maintain sample temperature between 65 and $70{ }^{\circ} \mathrm{C}$.

The samples were offered to the panellists in three sections. In each section, the panellists were offered four goat meat samples, one from each treatment, followed by water and an unsalted cracker. The colour (visual appeal) of the goat meat was observed and scored by panellists in samples of fresh goat meat.

\subsection{Statistical analysis}

The data were submitted to analysis of variance (ANOVA) using the $\mathrm{F}$ test to compare the mean squares and to determine the significance of the effect of genotype in a completely randomised design with four genetic groups and eight repetitions using the statistical program Statistical Analysis System (SAS), version 6.12 (STATISTICAL..., 1996). The averages were compared using the Tukey test at $5 \%$ probability. The statistical model is presented in Equation 1

$\mathrm{Y}_{\mathrm{ijk}}=\mu+\mathrm{Gi}+\mathrm{e}_{\mathrm{ijk}}$

$Y_{\mathrm{ijk}}=$ observed value for each characteristic relating to animal genetic group $\mathrm{i} ; \mu=$ overall population; $\mathrm{Gi}=$ effect of genetic group i $(\mathrm{i}=1,2,3,4) ; \mathrm{e}_{\mathrm{ijk}}=$ random error associated with each observation ijk.

\section{Results and discussion}

Data on the production of goats during the feeding period are shown in Table 2. Very similar carcass (12.7 to $13.8 \mathrm{~kg}$ ) and non-significantly different carcass yields ( 49 to $46 \%$ ) were found for the four crossbred genotypes, but $1 / 2$ Boer $+1 / 2$ SPRD and $1 / 2$ Anglo Nubian $+1 / 2$ SPRD goats had higher carcass yields than the pure-bred Boer and 3/4 Boer $+1 / 4$ SPRD goats. However, the days on feed differ significantly $(P<0.05)$ among the four groups. The highest mean daily gain ( $166 \mathrm{~g}$ for the pure-bred Boer goats) resulted in the least time ( 63 days) necessary to achieve the final weight of $29 \mathrm{~kg}$, but the difference in daily weight gain was not significant. The short period of confinement of the pure-bred Boer goats resulted from the selection of this type of goat for meat production.

The results show good performance in all the genetic groups studied; consequently, no significant differences were detected in the SPRD goats crossbred with Boer or Anglo Nubian breeds. The live slaughter weight of the animals was $29.0 \pm 2.0 \mathrm{~kg}$, which was reached during the confinement period ranging from 63 to 84 days. The variation in standard deviations occurred because some animals did not respond well to confinement since the daily gains in weight at the beginning of the experiment ranged from 150 to $200 \mathrm{~g}$.

The $\mathrm{pH}$ decline curve (Figure 1) during the 24 hours post-mortem shows exponential behaviour, and it is more pronounced in the first few post-mortem hours. There appears

Table 2. Effect of crossbreeding on the rearing of goats (mean values + standard deviation; $\mathrm{n}=32$ (4 genetic groups of 8 goats)).

\begin{tabular}{lcccc}
\hline \multicolumn{1}{c}{ Parameter } & Pure-bred Boer & $3 / 4$ Boer $+1 / 4$ SPRD & $1 / 2$ Boer $+1 / 2$ SPRD & $1 / 2$ Anglo Nubian $+1 / 2$ SPRD \\
\hline Days on feed & $62.7 \pm 9.6^{c}$ & $72 \pm 8.5^{\mathrm{bc}}$ & $84 \pm 0.0^{\mathrm{a}}$ & $77.5 \pm 12.1^{\mathrm{ab}}$ \\
Initial live weight (kg) & $19 \pm 3.8$ & $18 \pm 1.5$ & $16.8 \pm 2.3$ & $18.3 \pm 2.1$ \\
Final live weight (kg) & $29.4 \pm 1.7$ & $29.2 \pm 1.3$ & $27.4 \pm 3.2$ & $29 \pm 1.4$ \\
Total weight gained (kg) & $10.4 \pm 2.8$ & $11.2 \pm 1 . .4$ & $10.6 \pm 5.1$ & $10.7 \pm 1.7$ \\
Mean daily gain (g) & $165.6 \pm 38.6$ & $157.6 \pm 24.0$ & $126.5 \pm 60.3$ & $139.9 \pm 23.6$ \\
Hot carcass (kg) & $13.9 \pm 1.1$ & $13.7 \pm 0.7$ & $12.9 \pm 1.7$ & $14.1 \pm 1.0$ \\
Carcass (kg) & $13.6 \pm 1.1$ & $13.4 \pm 0.6$ & $12.7 \pm 1.7$ & $13.8 \pm 1.0$ \\
Yield (\%) & $46.3 \pm 2.4$ & $46.0 \pm 2.3$ & $48.8 \pm 2.0$ & $49.0 \pm 3.4$ \\
\hline
\end{tabular}

${ }^{\text {abc }}$ Means bearing different superscripts in the same row are significantly different by the Tukey test $(\mathrm{p}<0.05)$. 
to be an efficient adjustment of the data around the regression curve, with $\mathrm{R}^{2}$ values of greater than $70 \%$.

The values of the temperature variation in the longissimus dorsi muscle are shown in Figure 2. Like the $\mathrm{pH}$ curve, the curve of temperature decline also showed exponential behaviour indicating a rapid drop in the first few post-mortem hours but with a tendency to stabilise 5 hours after slaughter.
The rapid decline in temperature was probably due to by the small carcass sizes and low levels of subcutaneous fat in goats. According to King et al. (2004), the decrease in $\mathrm{pH}$ in the first few post-mortem hours reduces the negative impact of low temperature on the hardness of the meat. Similar behaviour was observed in this work, as the first 5 post-mortem hours related to temperatures around $5^{\circ} \mathrm{C}$ for the different genetic groups.

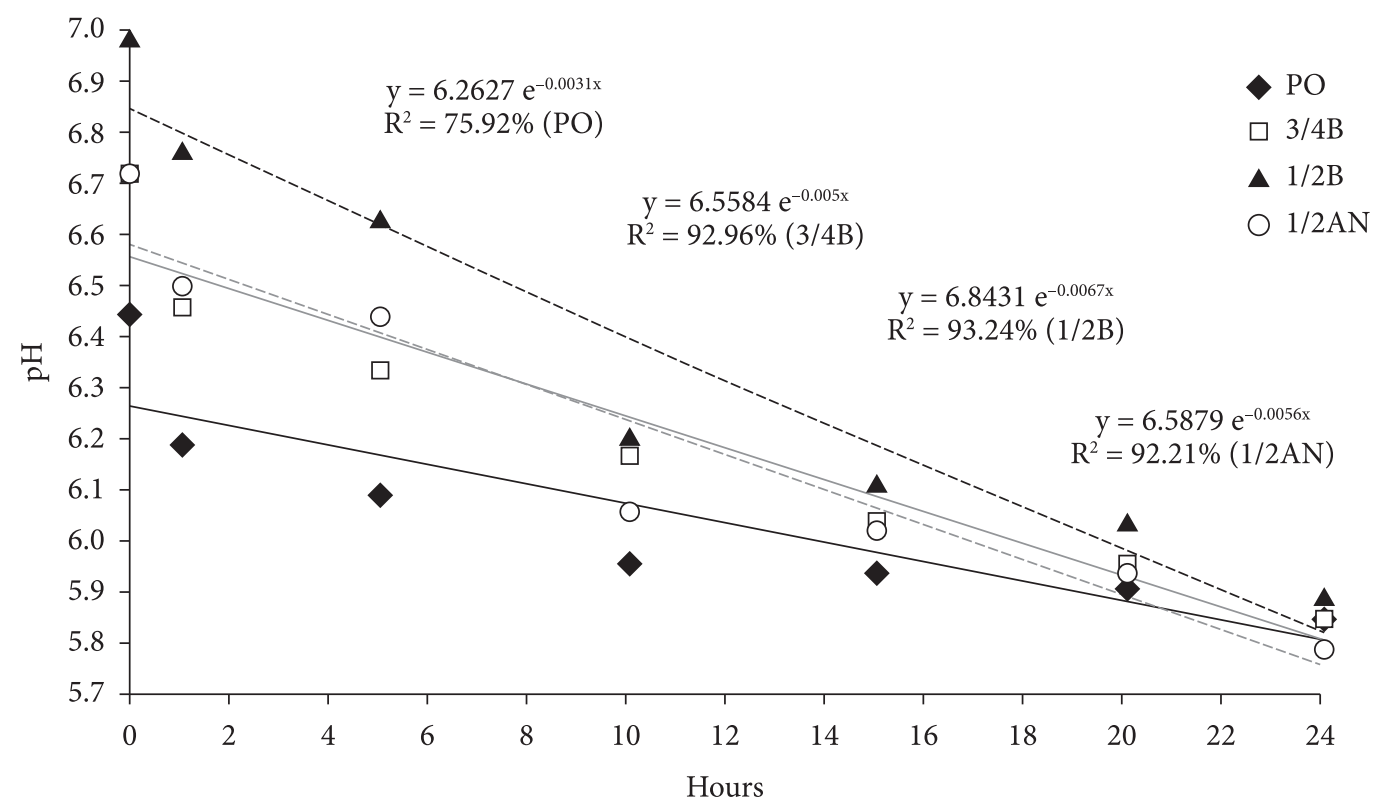

Figure 1. Post-mortem $\mathrm{pH}$ curve of longissimus dorsi muscle of Pure Boer (PO), 3/4 Boer $+1 / 4$ SPRD (3/4 B), $1 / 2$ Boer $+1 / 2$ SPRD (1/2 B) e $1 / 2$ Anglo Nubiano + $1 / 2$ SPRD (1/2 AN).

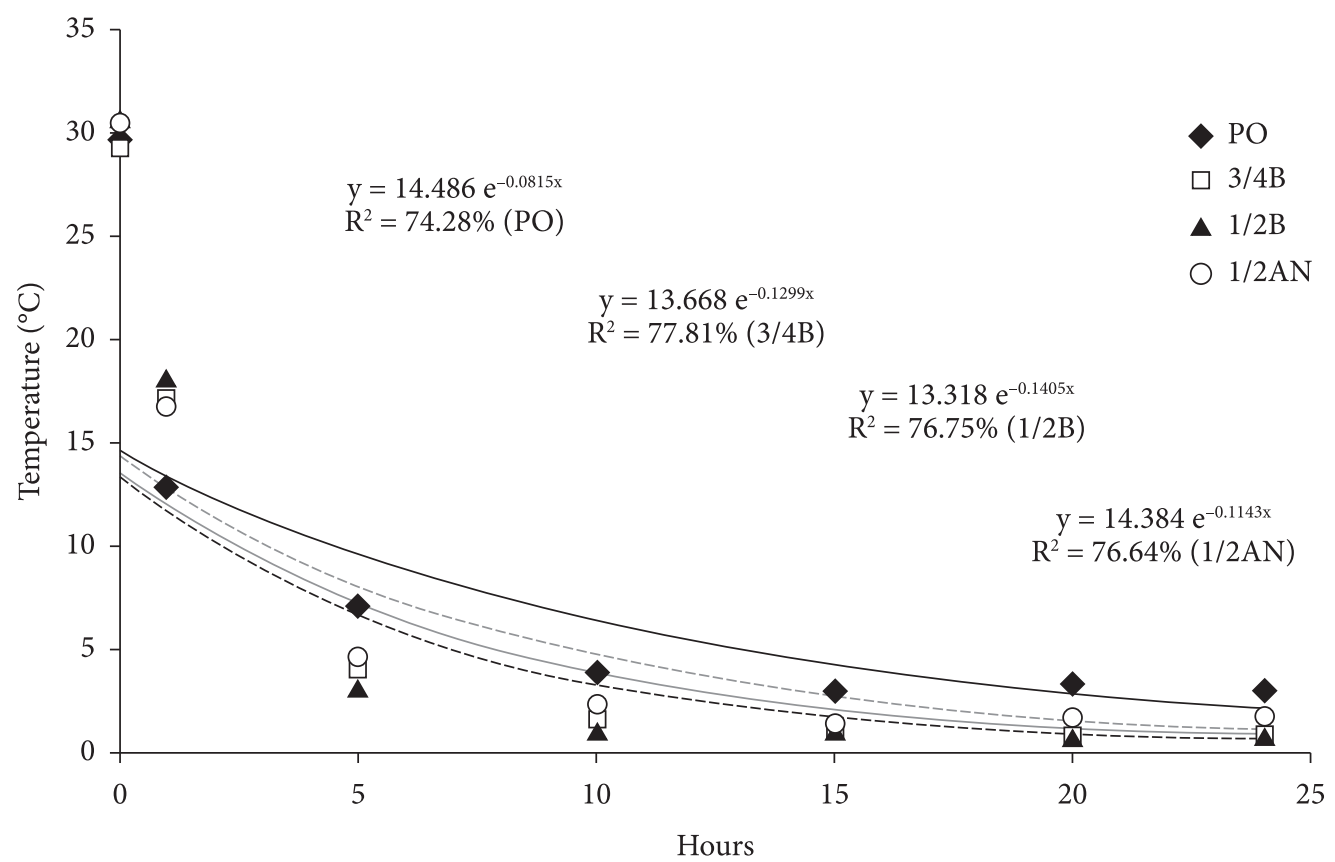

Figure 2. Post-mortem temperature curve of longissimus dorsi muscle of Pure Boer (PO), 3/4 Boer + 1/4 SPRD (3/4 B), $1 / 2$ Boer $+1 / 2$ SPRD (1/2 B) e $1 \frac{1}{2}$ Anglo Nubiano $+1 / 2$ SPRD (1/2 AN). 
Similar results for post-mortem $\mathrm{pH}$ and temperature were observed in goat meat by Gadiyaram et al. (2008), Kannan, Gadiyaram and Galipalli (2006) and King et al. (2004), all of whom reported exponential behaviour most pronounced in the first 6 post-mortem hours. In fact, the 24-hour $\mathrm{pH}$ was similar for the four groups in the present study; the onset of rigor mortis occurred at $\mathrm{pH} 5.8$ and constant temperature in the Longissimus dorsi muscle. The $\mathrm{pH}$ post-mortem in the present study was higher than the value reported by Monte et al. (2007) for goat meat of similar genotypes, in which the final $\mathrm{pH}$ of the cold carcass was 5.60, and no significance differences were detected between the exotic and SPRD genotypes.

According to the data shown in Table 3, the physicochemical and sensory attributes of goat meat of different genetic groups finished in feedlot. There were no significant $(\mathrm{P}>0.05)$ differences in the WHC or $\mathrm{a}^{*}$ attributes of goat meat. The LWC, $\mathrm{SF}, \mathrm{b}^{\star}$, and $\mathrm{L}^{\star}$ values were significantly affected $(\mathrm{P}<0.05)$ by the crossing. The differences found for LWC resulted from genetic differences between the groups because there was no variation in the final $\mathrm{pH}$, temperature, or fat content (MADRUGA et al., 2009). The pure-bred Boer and $1 / 2$ Anglo Nubian $+1 / 2$ SPRD goats stood out, with values of 48.1 and 48.6 g. $100 \mathrm{~g}^{-1}$, respectively, indicating more succulent meat.

Pratiwi, Murray e Taylor (2007) reported similar values for the LWC in Australian feral goat meat; however, lower values of LWC were reported by Dhanda, Taylor e Murray (2003), Kadim et al. (2003), Borges et al. (2006), and Madruga et al. (2008) in goat meat from different native breeds.

Shear force $\left(\mathrm{Kgf.cm}^{-2}\right)$ was similar $(9.4 ; 10.2$ and 9.1) among the three groups (pure-bred Boer, $3 / 4$ Boer $+1 / 4$ SPRD and $1 / 2$ Anglo Nubian $+1 / 2$ SPRD goats, respectively) and higher than that of the $1 / 2$ Boer $+1 / 2$ SPRD goats (7.4). According to Schönfeldt et al. (1993), WBS values exceeding 5.5 would often be considered objectionably tough by both a trained sensory panel and typical consumers.

Among the ante-mortem factors contributing to meat quality, genotype is highly correlated with hardness (SILVA SOBRINHO et al., 2005). Webb, Casey and Simela
(2005) reported that the variation in the values of the shear force reported by several authors can be attributed to differences in nutrition, age, and the final $\mathrm{pH}$ of muscle. In the present study, no variation in these parameters was observed between the genotypes. Similar values of SF were reported by Kadim et al. (2003) in the Longissimus dorsi muscle of Batin $\left(7.22 \mathrm{kgf.cm}{ }^{-2}\right)$, Dhofari (7.43 kgf.cm $\left.{ }^{-2}\right)$, and Jabal Khaddar $\left(7.67 \mathrm{kgf.cm}{ }^{-2}\right)$ goats. Gadiyaram et al. (2008), studying the effect of electrical stimulation post-mortem on the meat quality of male Boer $\times$ Spanish $\times$ Kiko goats, reported SF values of 4.6 and $3.8 \mathrm{kgf.cm}{ }^{-1}$ at 1 and 4 days post-mortem, respectively. Sen, Santra e Karim (2004) found values of $4.2 \mathrm{kgf.cm}{ }^{-2}$ and $7.42 \mathrm{kgf.cm}^{-2}$ in the meat of crossbred Boer and native goats, respectively, in India.

Only $\mathrm{b}^{*}$ and $\mathrm{L}^{*}$ were influenced $(\mathrm{P}<0.05)$ by genotype. Changes in the light intensity of the meat are related to the physical state of the meat, the final $\mathrm{pH}$ of the muscle, the structure of muscle fibres, and the commencement of rigor mortis. The pure-bred Boer goats had higher lightness scores $\left(L^{*}=40.3\right)$. These results were similar to those reported by King et al. (2004), who found $\mathrm{L}^{\star}$ values of 44.8 for Boer meat. The $b^{\star}$ (yellowness) parameter was low in the genotypes studied; it probably resulted from the low percentages of fat found in the goat meat (MADRUGA et al., 2009); the lowest fat content was found in the $1 / 2$ Anglo Nubian $+1 / 2$ SPRD goats.

The red $\left(\mathrm{a}^{*}\right)$ intensity values were between 14.4 and 13.5 in the longissimus dorsi muscle, indicating a light-red meat, which can be explained by the fact that young animals were used for this experiment. The concentration of myoglobin is not high in young animals, but it increases with age (BONAGURIO et al., 2003; KANNAN; KOUAUKOU; GELAYE, 2001).

The WHC values were between 70.4 and $79.1 \mathrm{~mL} .100 \mathrm{~g}^{-1}$, with no significant differences $(\mathrm{p}>0.05)$ between genotypes. The similarity in the WHC values of goat meat in this study probably resulted from the similarity of $\mathrm{pH}$ values found among the genotypes studied; these values were also not influenced ( $p>0.05$ ) by genotype. According to Lanza et al. (2003), even if small differences in $\mathrm{pH}$ values are detected, they generally produce changes in the WHC of red meat.

Table 3. Effect of crossbreeding on the physical and sensorial parameters of goat meat (mean values + standard deviation; $\mathrm{n}=32(4$ genetic groups of 8 goats)).

\begin{tabular}{|c|c|c|c|c|}
\hline Parameter & Pure-bred Boer & $3 / 4$ Boer + 1/4 SPRD & $1 / 2$ Boer $+1 / 2$ SPRD & $1 / 2$ Anglo Nubian $+1 / 2$ SPRD \\
\hline $\mathrm{WHC}^{1}\left(\mathrm{~mL} .100 \mathrm{~g}^{-1}\right)$ & $77.9 \pm 9.9$ & $79.1 \pm 12.5$ & $70.4 \pm 3.2$ & $73.6 \pm 9.2$ \\
\hline $\mathrm{LWC}^{2}\left(\mathrm{~g} .100 \mathrm{~g}^{-1}\right)$ & $48.1 \pm 3.1^{\mathrm{ab}}$ & $44.8 \pm 2.5^{\mathrm{c}}$ & $45.0 \pm 1.9^{\mathrm{bc}}$ & $48.6 \pm 2.9^{\mathrm{a}}$ \\
\hline $\mathrm{SF}^{3}\left(\mathrm{Kgf.cm}^{-2}\right)$ & $9.4 \pm 2.7^{\mathrm{ab}}$ & $10.2 \pm 2.1^{\mathrm{a}}$ & $7.4 \pm 1.2^{\mathrm{b}}$ & $9.1 \pm 2.2^{\mathrm{ab}}$ \\
\hline$a^{*}$ & $14.4 \pm 1.1$ & $13.5 \pm 1.0$ & $13.5 \pm 0.6$ & $14.4 \pm 1.0$ \\
\hline$b^{*}$ & $1.9 \pm 0.7^{\mathrm{a}}$ & $1.1 \pm 0.4^{\mathrm{b}}$ & $1.2 \pm 0.5^{\mathrm{ab}}$ & $0.7 \pm 0.5^{\mathrm{b}}$ \\
\hline $\mathrm{L}^{*}$ & $40.3 \pm 2.3^{\mathrm{a}}$ & $39.6 \pm 1.7^{\mathrm{ab}}$ & $38.8 \pm 2.3^{\mathrm{ab}}$ & $36.7 \pm 2.5^{\mathrm{b}}$ \\
\hline Colour in natura & $6.1 \pm 1.6^{\mathrm{a}}$ & $3.2 \pm 2.2^{\mathrm{b}}$ & $3.8 \pm 2.0^{\mathrm{b}}$ & $5.5 \pm 1.6^{\mathrm{a}}$ \\
\hline Odour & $5.7 \pm 1.6^{\mathrm{a}}$ & $4.5 \pm 1.9^{\mathrm{b}}$ & $5.5 \pm 1.3^{\mathrm{ab}}$ & $5.7 \pm 1.7^{\mathrm{a}}$ \\
\hline Flavour & $5.5 \pm 1.8^{\mathrm{ab}}$ & $5.2 \pm 1.7^{\mathrm{ab}}$ & $4.7 \pm 1.8^{\mathrm{b}}$ & $6.1 \pm 1.5^{\mathrm{a}}$ \\
\hline Hardness & $3.7 \pm 1.8$ & $4.5 \pm 2.4$ & $3.2 \pm 2.0$ & $3.5 \pm 1.7$ \\
\hline Juiciness & $5.0 \pm 1.9$ & $4.0 \pm 2.2$ & $4.1 \pm 2.1$ & $4.9 \pm 2.3$ \\
\hline Overall acceptability & $5.2 \pm 1.8$ & $5.3 \pm 1.5$ & $4.3 \pm 1.6$ & $4.2 \pm 2.7$ \\
\hline
\end{tabular}

${ }^{\mathrm{abc}}$ Means bearing different superscripts in the same row are significantly different by the Tukey test $(\mathrm{p}<0.05) .{ }^{1}$ Water-holding capacity. ${ }^{2}$ Loss of weight from cooking. ${ }^{3}$ Shear force. 
The colour (visual appeal) of raw pure-bred Boer and $1 / 2$ Anglo Nubian $+1 / 2$ SPRD goat meat was rated significantly $(\mathrm{P}<0.05)$ better than that of the other two groups (Table 3$)$, which was a reflection of the darker red colour ( $\mathrm{a}^{*}$ parameter). Odour and flavour were also rated to be significantly different $(\mathrm{P}<0.05)$ among the samples; the $3 / 4$ Boer $+1 / 4$ SPRD and $1 / 2$ Boer $+1 / 2$ SPRD were given the lowest scores (4.59) for these attributes.

The hardness and juiciness of the goat meat were the same for the four genotypes. Monte et al. (2007) reported that goat meat from Anglo Nubian and Boer crossbreeds, when tested by a sensorial panel, had lower hardness than SPRD goat meat. Lastly, with regard to the overall acceptability score, the four genotypes were rated nearly equal and were similar to the results reported by Dhanda, Taylor and Murray (2003), Sen, Santra and Karim (2004), Pratiwi, Murray and Taylor (2007), and Madruga et al. (2008). The data obtained during the present research suggest that the crossing of SPRD goats, a native genetic group with low genetic aptitude for meat production, with breeds selected for meat production, such as Boer and Anglo Nubian, can improve the sensory attributes of goat meat.

\section{Conclusion}

The crossbreeding of Boer or Anglo Nubian with genetic group SPRD goats, even when $50 \% / 50 \%$, resulted in a meat of high quality, as confirmed by high water holding capacity, soft texture, and low $\mathrm{b}^{\star}$ intensity. The favourable sensory evaluation of the meat indicates that the flavour, odour, and in natura colour of the goat meat were affected by cross breeding and the pure-bred Boer, $3 / 4$ Boer $+1 / 4$ SPRD, and $1 / 2$ Anglo Nubian $+1 / 2$ SPRD goats were considered to be equivalent in flavour.

\section{Acknowledgement}

The authors are grateful for the financial support provided by The National Council for Scientific and Technological Development-CNPq, (Conselho Nacional de Desenvolvimento Científico e Tecnológico), Financing Agency for Studies and Projects - FINEP (Financiadora de Estudos e Projetos ), and the State of Paraiba Agricultural and Cattle Raising Research Company (EMEPA).

\section{References}

ABULARACH, M. L. S.; ROCHA, C. E.; FELICIO, P. E. Características de qualidade do contrafilé (m. L. dorsi) de touros jovens da raça Nelore. Ciência e Tecnologia de Alimentos, v. 18, n. 2, p. 205-210, 1998. http://dx.doi.org/10.1590/S0101-20611998000200012

ASSOCIATION OF OFFICIAL ANALYTICAL CHEMISTRY - AOAC. Official methods of analysis. 19th ed. Washington: AOAC International, 2000. 1219 p.

BONAGURIO, S. et al. Qualidade da carne de cordeiros Santa Inês puros e mestiços com Texel abatidos com diferentes pesos. Brazilian of Journal Animal Science, v. 32, n. 6, p. 1981-1991, 2003.

BORGES, A. S. et al. Medições instrumentais e sensoriais de dureza e suculência da carne caprina. Ciência e Tecnologia de Alimentos, v. 26 , n. 4 , p. 891-896, 2006. http://dx.doi.org/10.1590/S010120612006000400028
DHANDA, J. S.; TAYLOR, D. G.; MURRAY, P. J. Growth, carcass and meat quality parameters of male goats: effects of genotype and liveweight at slaughter. Small Ruminants Research, v. 50, p. 57-66, 2003. http://dx.doi.org/10.1016/S0921-4488(03)00112-3

DUCKETT, S. K. et al. Tenderness of normal and callipyge lamb aged fresh or after freezing. Meat Science, v. 49, n. 1, p. 19-26, 1998a. http://dx.doi.org/10.1016/S0309-1740(97)00100-9

DUCKETT, S. K. et al. Effect of freezing on calpastatin activity and tenderness of callipyge lamb. Journal Animal Science, v. 76, n. 1, p. 1869-1874, 1998b. PMid:9690642.

GADIYARAM, K. M. et al. Effects of postmortem carcass electrical stimulation on goat meat quality characteristics. Small Ruminants Research, v. 78, p. 106-114, 2008. http://dx.doi.org/10.1016/j. smallrumres.2008.05.013

INSTITUTO BRASILEIRO DE GEOGRAFIA E ESTATÍSTICA - IBGE. 2008. Censo Agropecuário - Brasil. 2008. Disponível em: <www.ibge.gov.br>. Acesso em: 21 mar. 2009.

KADIM, I. T. et al. An evaluation of the growth, carcass and meat quality characteristics of goat breeds. Meat Science, v. 66, p. 203-210, 2003. http://dx.doi.org/10.1016/S0309-1740(03)00092-5

KANNAN, G.; KOUAUKOU, B.; GELAYE, S. Color changes reflecting myoglobin and lipid oxidation in chevon cuts during refrigerated disply. Small Ruminant Research, v. 42, p. 67-75, 2001. http:// dx.doi.org/10.1016/S0921-4488(01)00232-2

KANNAN, G.; GADIYARAM, K. M.; GALIPALLI, S. Meat quality in goats as influenced by dietary protein and energy levels, and postmortem aging. Small Ruminant Research, v. 61, p. 45-52, 2006. http://dx.doi.org/10.1016/j.smallrumres.2005.01.006

KING, D. A. et al. High voltage electrical stimulation enhances muscle tenderness, increases aging response, and improves muscle color from cabrito carcasses. Meat Science, v. 68, p. 529-535, 2004. PMid:22062529. http://dx.doi.org/10.1016/j.meatsci.2004.05.003

LANZA, M. et al. Peãs (Pisum sativum L.) as in alternative protein source in lamb diets: growth performances and carcass and meat quality. Small Ruminant Research, v. 47, p. 63-68, 2003. http:// dx.doi.org/10.1016/S0921-4488(02)00244-4

MADRUGA, M. S. et al. Chemical composition and fat profile of meat from crossbred goats reared under feedlot systems. Brazilian of Journal Animal Science, v. 38, n. 3, p. 547-552, 2009.

MADRUGA, M. S. et al. Meat quality of Moxotó and Canindé goats as affected by two levels of feeding. Meat Science, v. 80, p. 1019-1023, 2008. PMid:22063831. http://dx.doi.org/10.1016/j. meatsci.2008.04.020

MADRUGA, M. S. et al. Características químicas e sensoriais de cortes comerciais de caprinos SRD e mestiços de Boer. Ciência e Tecnologia de Alimentos, v. 25, n. 4, p. 713-719, 2005. http://dx.doi. org/10.1590/S0101-20612005000400014

MADRUGA. M.S. Qualidade química. sensorial e aromática da carne caprina: mitos e verdades. In: ENCONTRO NACIONAL PARA O DESENVOLVIMENTO DA ESPÉCIE CAPRINA, 8., 2004, São Paulo. Anais... Botucatu, 2004. p. 215-234.

MILLER, R.; GRONINGER JUNIOR, H. S. Functional properties of enzyme modified acylated fish protein derivatives. Journal Food Science and Technology, v. 41, p. 268-272, 1978.

MONTE, A. L. S. et al. Parâmetros físicos e sensoriais de qualidade da carne de cabritos mestiços de diferentes grupos genéticos. Ciência e Tecnologia de Alimentos, v. 27, n. 2, p. 233-238, 2007. http:// dx.doi.org/10.1590/S0101-20612007000200004

NATIONAL RESEARCH COUNCIL - NRC. Nutrient requirements of goats Angora, dairy and meat in temperate and tropical countries. Washington: National Academy Press, 1981. p. 87 
PRATIWI, N. M. W.; MURRAY, P. J.; TAYLOR, D. G. Feral goats in Australia: A study on the quality and nutritive value of their meat. Meat Science, v. 75, p. 168-177, 2007. PMid:22063425. http://dx.doi. org/10.1016/j.meatsci.2006.06.026

STATISTICAL ANALYSIS SYSTEM - SAS. User's guide to statistics. versão 6.12. Cary: North Caroline State University, 1996. 956 p.

SCHÖNFELDT, H. C. et al. Cooking and juiciness-related quality characteristics of goat and sheep meat. Meat Science, v. 34, p. 381-394, 1993. http://dx.doi.org/10.1016/0309-1740(93)90085-V

SEN, A. R.; SANTRA, A.; KARIM, S. A. Carcass yield, composition and meat quality attributes of sheep and goat under semiarid conditions.
Meat Science, v. 66, p. 757-763, 2004. http://dx.doi.org/10.1016/ S0309-1740(03)00035-4

SHRESTH, J. N. B.; FAHMY, M. H. Breeding goats for meats production: a review. 1. Genetic resources, management and breed evaluation. Small Ruminant Research, v. 58, p. 93-106, 2005.

SILVA SOBRINHO, A. G. et al. Características de qualidade da carne de ovinos de diferentes genótipos e idades ao abate. Brazilian of Journal Animal Science, v. 34, n. 3, p. 1070-1078, 2005.

STONE, H. et al. Sensory evaluation by quantitative descriptive analysis. Food Technology, v. 28, p. 24-34, 1974.

WEBB, E. C.; CASEY, N. H.; SIMELA, L. Goat meat quality. Small Ruminant Research, v. 60, p. 153-166, 2005. 